Jurnal Mengenai Dasar-Dasar Pemikiran Hukum: Filsafat dan IImu Hukum Tersedia online di https://ejournal2.undip.ac.id/index.php/crepido/

Volume 01, Nomor 01, Juli 2019

\title{
PEMAHAMAN TERHADAP ASAS KEPASTIAN HUKUM MELALUI KONSTRUKSI PENALARAN POSITIVISME HUKUM
}

\author{
Mario Julyano*, Aditya Yuli Sulistyawan \\ Fakultas Hukum, Universitas Diponegoro \\ Jl. Prof. Soedarto, S.H., Tembalang, Semarang \\ mariojuliano87@gmail.com
}

\begin{abstract}
The principle of legal certainty is a principle which, according to Gustav Radbruch, is included in the basic legal value. This principle basically expects and requires the law to be made definitively in written form. The existence of this principle is important because it will guarantee the clarity of a positive legal product that exists. The important meaning of this principle also has a similarity (similarity) with the main idea that exists in the construction of legal positivism reasoning, namely clarity (certainty). Therefore, this paper aims to achieve an understanding of the principle of legal certainty by using the legal positivism construction.
\end{abstract}

Keywords: Understanding; Legal Certainty; Legal Positivism

\begin{abstract}
Abstrak
Asas kepastian hukum merupakan suatu asas yang menurut Gustav Radbruch termasuk ke dalam nilai dasar hukum. Asas ini pada pokoknya mengharapkan dan mewajibkan hukum dibuat secara pasti dalam bentuk yang tertulis. Keberadaan asas ini menjadi penting karena akan menjamin kejelasan dari suatu produk hukum positif yang ada. Makna penting dari asas ini pun memiliki suatu kesamaan (similarity) dengan gagasan utama yang ada pada konstruksi penalaran positivisme hukum, yakni kejelasan (certainty). Oleh karena itu, pada tulisan ini hendak dicapai pemahaman mengenai asas kepastian hukum dengan menggunakan konstruksi penalaran positivisme hukum.
\end{abstract}

Kata Kunci: Pemahaman; Kepastian Hukum; Positivisme Hukum

\section{A. Pendahuluan}

Di dalam suatu peraturan hukum, terkandung asas-asas hukum yang menjadi dasar pembentuknya. Dikatakan oleh Satjipto Rahardjo, bahwa asas hukum dapat diartikan sebagai "jantungnya" perarturan hukum, ${ }^{1}$ sehingga untuk memahami suatu peraturan hukum diperlukan adanya asas hukum. Dengan bahasa lain, Karl Larenz dalam bukunya Methodenlehre der Rechtswissenschaft menyampaikan bahwa asas hukum merupakan ukuran-ukuran hukum ethis yang memberikan arah kepada pembentukan hukum. ${ }^{2}$ Oleh karena asas hukum mengandung tuntutan etis maka asas hukum dapat dikatakan sebagai jembatan antara peraturan hukum dengan cita-cita sosial dan pandangan etis masyarakat.

\footnotetext{
${ }^{1}$ Satjipto Rahardjo, IImu Hukum, Citra Aditya Bakti: Bandung, 2012, hlm. 45

2 Dewa Gede Atmaja, "Asas-Asas Hukum Dalam Sistem Hukum”, Jurnal Kertha Wicaksana, Volume 12, Nomor 2, 2018, hlm. 146
} 
Dalam pembentukan aturan hukum, terbangun asas yang utama agar tercipta suatu kejelasan terhadap peraturan hukum, asas tersebut ialah kepastian hukum. Gagasan mengenai asas kepastian hukum ini awalnya diperkenalkan oleh Gustav Radbruch dalam bukunya yang berjudul "einführung in die rechtswissenschaften". Radbruch menuliskan bahwa di dalam hukum terdapat 3 (tiga) nilai dasar, yakni: ${ }^{3}$ (1) Keadilan (Gerechtigkeit); (2) Kemanfaatan (Zweckmassigkeit); dan (3) Kepastian Hukum (Rechtssicherheit).

Dalam bukunya IImu Hukum, Satjipto Rahardjo meragakan ketiga nilai dasar tersebut dengan landasan kesahan berlakunya. Ragaan tersebut ialah sebagai berikut: ${ }^{4}$

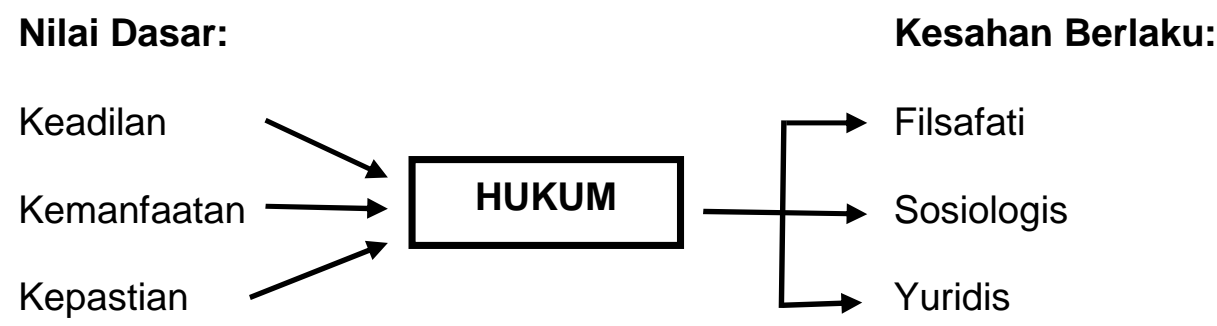

Digambarkan oleh Mirza Satria Buana dalam tesisnya bahwa ketiga nilai dasar tersebut ibarat seorang "raja" yang saling bertengkar (spannungsverhaltnis) untuk dapat diterapkan dalam hukum. ${ }^{5}$

Kembali pada pembahasan mengenai asas kepastian hukum, sejatinya keberadaan asas ini dimaknai sebagai suatu keadaan dimana telah pastinya hukum karena adanya kekuatan yang konkret bagi hukum yang bersangkutan. Keberadaan asas kepastian hukum merupakan sebuah bentuk perlindungan bagi yustisiabel (pencari keadilan) terhadap tindakan sewenangwenang, yang berarti bahwa seseorang akan dan dapat memperoleh sesuatu yang diharapkan dalam keadaan tertentu. ${ }^{6}$ Pernyataan tersebut sejalan dengan apa yang dikatakan oleh Van Apeldoorn bahwa kepastian hukum memiliki dua segi, yaitu dapat ditentukannya hukum dalam hal yang konkret dan keamanan hukum. Hal memiliki arti bahwa pihak yang mencari keadilan ingin mengetahui apa yang menjadi hukum dalam suatu hal tertentu sebelum ia memulai perkara dan perlindungan bagi para pencari keadilan.

\footnotetext{
${ }^{3}$ Satjipto Rahardjo, Op.Cit., hlm. 19

${ }^{4}$ Ibid., hlm. 20

${ }^{5}$ Mirza Satria Buana, Hubungan Tarik-Menarik Antara Asas Kepastian Hukum (Legal Certainpi) Dengan Asas Keadilan (Substantial Justice) Dalam Putusan-Putusan Mahkamah Konstltusi, Yogyakarta: Tesis Magister Ilmu Hukum Universitas Islam Indonesia, 2010, hlm. 34

${ }^{6}$ Sudikno Mertokusumo, Bab-Bab Tentang Penemuan Hukum, Citra Aditya Bakti: Bandung, 1993, hlm. 2.
} 
Lebih lanjut terkait kepastian hukum, Lord Lloyd mengatakan bahwa: “...law seems to require a certain minimum degree of regularity and certainty , $f$ or without that it would be impossible to assert that what was operating in a given territory amounted to a legal system"

Dari pandangan tersebut maka dapat dipahami bahwa tanpa adanya kepastian hukum orang tidak tahu apa yang harus diperbuatnya dan akhirnya timbulah ketidakpastian (uncertainty) yang pada akhirnya akan menimbulkan kekerasan (chaos) akibat ketidaktegasan sistem hukum. Sehingga dengan demikian kepastian hukum menunjuk kepada pemberlakuan hukum yang jelas, tetap dan konsisten dimana pelaksanaannya tidak dapat dipengaruhi oleh keadaan-keadaan yang sifatnya subjektif. $^{8}$

Meskipun dikatakan bahwa asas hukum merupakan jantung dari peraturan hukum, akan tetapi tidak dapat disamakan antara asas hukum dan norma hukum dalam bentuk hukum positif. Asas hukum hanya bersifat mengatur dan menjelaskan (eksplanasi), dimana tujuannya hanya memberi ikhtisar dan tidak normatif. ${ }^{9}$ Oleh karena itu asas hukum tidak termasuk hukum positif dan tentu tidak dapat diterapkan secara langsung untuk menyelesaikan sengketa hukum. Dalam hal ini, Van Eikema Hommes secara tegas mengatakan asas hukum tidak boleh dianggap sebagai norma-norma hukum yang konkrit, tetapi dipandang sebagai dasar-dasar umum atau petunjuk-petunjuk bagi hukum yang berlaku. ${ }^{10}$

Dalam ranah hukum, sejatinya terdapat banyak sekali asas yang menjadi landasan untuk membentuk peraturan hukum. ${ }^{11}$ Pada penulisan kali ini tidak akan dibahas mengenai asas-asas pembentuk peraturan hukum secara komperhensif, melainkan pembahasan akan berpusat pada salah satu asas yang juga menurut Gustav Radbruch dapat dikatakan sebagai suatu nilai dasar hukum, yakni Kepastian Hukum. Asas kepastian hukum pada tulisan ini coba untuk dipahami bagaimana korelasinya dengan penalaran Positivisme Hukum. Dengan adanya tulisan ini diharapkan mampu menerangkan mengenai hubungan asas kepastian hukum dengan penalaran positivisme hukum.

\footnotetext{
${ }_{7}^{7}$ Lord Lloyd dalam Mirza Satria Buana, Loc. Cit.,

${ }^{8}$ R. Tony Prayogo, "Penerapan Asas Kepastian Hukum Dalam Peraturan Mahkamah Agung Nomor 1 Tahun 2011 Tentang Hak Uji Materiil Dan Dalam Peraturan Mahkamah Konstitusi Nomor 06/Pmk/2005 Tentang Pedoman Beracara Dalam Pengujian Undang-Undang ", Jurnal Legislasi Indonesia, Volume 13, Nomor 2, 2016, hlm.194

${ }^{9}$ Sidharta, Karakteristik Penalaran Hukum Dalam Konteks Keindonesiaan, Alumni: Bandung, 2006, hlm. 204.

${ }^{10}$ Notohamidjojo, Soal-Soal Pokok Filsafat Hukum, BPK Gunung Mulia: Jakarta,1975, hlm. 49

${ }^{11}$ Misalnya J. Gijssels, seperti dikutip dari "Bruggink, Refleksi tentang Ilmu Hukum, Alih Bahasa, Arief Sidharta, Citra Adytya Bakti: Bandung, 1999, hlm. 33.", la mengemukakan sebuah daftar yang memuat 83 asas hukum tanpa menatanya ke dalam perbedaan tataran atau memberikan penataan tertentu.
} 


\section{B. Pembahasan}

\section{Penalaran Positivisme Hukum}

Penalaran hukum menurut Shidarta pada dasarnya adalah kegiatan berpikir problematis. ${ }^{12}$ Di dalam bukunya ia mengutip Visser't Hooft yang mengatakan bahwa:"The object of a scientific inquiry is discovery; the object of a legal inquiry is decision". Kegiatan berpikir ini berada dalam wilayah penalaran praktis, seperti apa yang dikatakan oleh Neil MacCormick: ${ }^{13}$ “... legal reasoning as one branch of practical reasoning which is the application by humans of their reason to deciding how it is right to conduct themselves in situation of choice"

Pola-pola penalaran hukum sangat dipengaruhi oleh sudut pandang dari subjek-subjek yang melakukan penalaran. Sudut pandang inilah yang kemudian bermuara menjadi orientasi berpikir yuridis, yakni berupa model-model penalaran di dalam disiplin hukum, khususnya sebagaimana dikenal luas sebagai aliran-aliran filsafat hukum. ${ }^{14}$ Apa yang dimaksud dengan sudut pandang ialah latar belakang subjektif dari suatu kerangka orientasi berpikir yuridis. Pada tulisan ini akan membahas salah satu pola penalaran hukum dengan sudut pandang aliran positivisme hukum.

Penalaran Positivisme Hukum berasal dari aliran positivisme. Aliran postivisme sendiri lahir dan dimatangkan oleh perubahan besar yang terjadi pada masyarakat Eropa terutama setelah meletus Revolusi Industri di Inggris dan revolusi borjuis di Perancis pada pertengahan abad ke-18. Dominasi kekuasaan raja dan gereja sebagai rezim pengetahuan (epistemologi) lama di Eropa mulai digugat, di mana-mana muncul pemikiran yang membuktikan kekeliruan berpikir biarawan dan raja serta mencari kebenaran yang esensial. ${ }^{15}$ Gairah mencari kebenaran ini tak terbendung dan meluap sejak masa Pencerahan (Aufklarung). ${ }^{16}$ Dominasi agama coba untuk digeser oleh ilmu pengetahuan yang mengakibatkan gereja mulai tidak diminati bersamaan dengan munculnya universitas-universitas, serta puncaknya pengetahuan metafisis diganti dengan pengetahuan rasional dan empiris. ${ }^{17}$ Puncak dari pembersihan pengetahuan dari kepentingan subjektif dicapai tak lain dengan gagasan dari tokoh kenamaan dari Perancis, yakni Auguste Comte.

Dalam gagasannya, Auguste Comte mencetuskan hukum tiga tahap atau yang kerap dikatakan sebagai "Law of three stages" (tahap teologis, metafisik, dan positif) dalam bukunya

\footnotetext{
${ }^{12}$ Shidarta, Hukum Penalaran dan Penalaran Hukum, Genta Publishing: Yogyakarta, 2013, hlm. 123

${ }^{13}$ Ibid.

${ }^{14}$ Ibid., hlm. 126

${ }^{15}$ Widodo Dwi Putro, Kritik Terhadap Paradigma Positivisme Hukum,Genta Publishing: Yogyakarta, 2011, hlm. 11

${ }_{16}^{16}$ bid., hlm.12

${ }^{17} \mathrm{lbid}$.
} 
yang berjudul Cours de Philosophie Positive. ${ }^{18}$ Makna positivis yang dikatakan oleh Comte dalam tahap tersebut dapat diartikan dalam 5 (lima) kemungknian, yakni: ${ }^{19}$

a. Sebagai lawan atau kebalikan yang bersifat khayal, maka positif diartikan sebagai pensifatan sesuatu yang nyata.

b. Sebagai lawan atau kebalikan sesuatu yang tidak bermanfaat, maka pengertian positif diartikan sebagai pensifatan sesuatu yang bermanfaat.

c. Sebagai lawan atau kebalikan sesuatu yang meragukan, maka pengertian positif diartikan sebagai pensifatan sesuatu yang sudah pasti.

d. Sebagai lawan atau kebalikan sesuatu yang kabur, maka pengertian positif diartikan sebagai pensifatan yang jelas atau tepat.

e. Sebagai lawan atau kebalikan sesuatu yang negative, maka pengertian positif dipergunakan untuk menunjukkan sifat-sifat filsafatnya, yang selalu menunju ke arah penataan atau penertiban.

Dari tahap perkembangan masyarakat tersebut, Auguste Comte ingin menegaskan bahwa setiap pengetahuan tidak boleh melampaui fakta, memperlakukan realitas sebagai suatu yang ada dan sebagai objek yang wajib dilepas dari bentuk konsepsi metafisis yang bersifat subjektif.

Seiring dengan pengaruh positivisme yang merambah dunia sains pada umumnya, maka tidak terkecuali disiplin hukum pun menghadapi keadaan serupa. Ketika para penganut positivisme mengamati hukum sebagai obyek kajian, mereka menganggap hukum hanya sebagai gejala sosial. ${ }^{20}$ Kaum positivisme pada umumnya hanya mengenal ilmu pengetahuan yang positif, demikian pula positivisme hukum hanya mengenal satu jenis hukum, yakni positivisme hukum. ${ }^{21}$ Istilah ini dalam definisinya yang paling tradisional tentang hakikat hukum, dimaknai sebagai norma-norma positif dalam sistem perundang-undangan. ${ }^{22}$

Menurut Erlyn Indarti, positivisme hukum (legal positivism) termasuk ke dalam "payung" paradigma positivisme bersama dengan aliran filsafat "legal philosophy" serta aliran "natural law". ${ }^{23}$ Menurutnya, legal positivism memandang hukum sebagai "law as what it is written in the books", yakni kaidah-kaidah positif yang berlaku umum in abstracto di suatu waktu/tempat

\footnotetext{
${ }^{18}$ Op.Cit., Shidarta, hlm. 69.

${ }^{19}$ lbid.

${ }^{20}$ Johni Najwan, "Implikasi Aliran Positivisme Terhadap Pemikiran Hukum”, Jurnal IImu Hukum Inovatif, Volume 2, Nomor 3, 2010, hlm. 24.

${ }^{21} \mathrm{lbid}$.

${ }^{22}$ Ibid., hlm. 198

${ }^{23}$ Erlyn Indarti, Diskresi dan Paradigma Sebuah Telaah Filsafat Hukum, Disampaikan pada Upacara Penerimaan Jabatan Guru Besar dalam Filsafat Hukum pada Fakultas Hukum Universitas Diponegoro, Badan Penerbit Universitas Diponegoro: Semarang,2010, hlm. 21
} 
tertentu ${ }^{24}$, bisa dikatakan bahwa hukum dimaknai sebagai ius constitutum, yaitu hukum yang ada dan berlaku.

Meski perkembangan penalaran positivisme hukum menjadi jelas dan terkonsep secara ilmiah baru setelah kemunculan paham positvisme oleh Comte, namun sejatinya penalaran terhadap positvisme hukum sudah berkembang sejak era pemikiran klasik di Cina. Han Feizi, seorang political phiolosophe mulai menyumbangkan pemikirannya terkait positivisme hukum di Cina pada masa Dinasti Han (206 SM - 220 M). Han Feizi berpendapat bahwa: ${ }^{25 "} A$ law is that which is recorded on the registers, set up in the government offices, and promogulated among the people"

Menurutnya hukum harus tercatat dan terekam dalam kantor pemerintahan dan diumumkan diantara orang-orang. Melalui hukum yang demikan maka rakyat akan mengetahui apa yang seharusnya mereka lakukan dan mereka tidak lakukan. Begitu hukum dibuat undangundang, penguasa harus tetap jeli dalam mengamati dan mengawasi perilaku rakyatnya. Karena ia memiliki wewenang, maka ia dapat menghukum siapa yang melanggar hukumnya dan memberi hadiah pada mereka yang menaati hukumnya. Dalam hal ini Han Feizi juga berpendapat jika: ${ }^{26}$

"In his rule of a state, the sage does not depend upon men doing good themselvesbut brings it about that the people can do no wrong, the entire state can be kept peaceful. He who rules a country makes use of the majority and neglects the few, and so does not concern himself with virtue but with law"

Dewasa ini positivisme hukum menurut Herbert Lionel Adolphus Hart, memiliki lima ciri yang terkandung di dalamnya, yakni: ${ }^{27}$

a. Hukum adalah suatu perintah yang datangnya dari manusia;

b. Tidak ada hubungan yang mutlak antara hukum dan kesusilaan, atau antara hukum yang berlaku (law as it is) dan hukum yang dicita-citakan (law as it ought to be);

c. Analisa mengenai pengertian hukum (legal concept) adalah penting dan harus dibedakan dari:

1) Penyelidikan secara sejarah tentang sebab-musabab hukum atau tentang sumber hukum;

2) Penyelidikan secara sosiologis mengenai hubungan hukum dengan gejala-gejala kemasyarakatan lainnya, penyelidikan hukum yang didasari pada kesusilaan, dan tujuantujuan sosial fungsi hukum dan sebagainya;

d. Sistem hukum adalah satu sistem logika yang tertutup (closed logical system), pada sistem tersebut ketentuan-ketentuan hukum yang benar bisa diperoleh dengan alat-alat logika

\footnotetext{
${ }^{24}$ Ibid.,

${ }^{25}$ Fung Yu-Lan, A Short History Of Chinese Philosophy, The Free Press: New York, 1966, hlm. 160.

${ }^{26}$ Ibid.

${ }^{27}$ Soetiksno, Filsafat Hukum bagian 1, Pradnya Paramita: Jakarta, 2004, hlm. 53
} 
(logical means) dari peraturan-peraturan hukum yang telah ditetapkan sebelumnya, tanpa memperhatikan tujuan-tujuan sosial, politik, ukuran-ukuran moral, dan sebagainya;

e. Pertimbangan-pertimbangan mengenai kesusilaan tidak dapat dibuat atau dibuktikan dengan mempegunakan argumentasi-argumentasi dan bukti-bukti berdasarkan logika, sebagai misalnya dalam keterangan-keterangan tentang fakta-fakta (non cognitivisme in ethics).

Selain dari pada 5 (lima) ciri tersebut, menurut Theo Huijbers positivisme hukum didasari atas beberapa prinsip, yakni: ${ }^{28}$

a. Hanya yang tampil dalam pengalaman dapat disebut benar;

b. Hanya apa yang sungguh-sungguh dapat dipastikan sebagai kenyataan dapat disebut benar. Itu berarti bahwa tidak semua pengalaman data disebut benar, tetapi hanya pengalaman yang mendapati kenyataan

c. Hanya melalui ilmu-ilmu pengetahuan dapat ditentukan apakah sesuatu yang dialam merupakan sungguh-sungguh suatu kenyataan.

Pada aliran positivisme, hukum terbit sebagai produk eksplisit suatu sumber kekuasaan politik tertentu yang berlegitimasi. Dalam hal ini, hukum utamanya terwujud sebagai perintahperintah eksplisit yang secara positif telah terumus jelas guna menjamin kepastiannya, seperti misalnya peraturan perundang-undangan yang berlaku secara nasional di suatu negara. Untuk itu, dapat dikatakan bahwa operasi aliran-aliran tersebut didasarkan utamanya pada norma positif legislatif dari ranah normatif positif ${ }^{29}$. Keberadaan positivisme hukum menunjukan fakta bahwa hukum itu dibuat dan dihapuskan oleh tindakan-tindakan manusia, jadi terlepas dari moralitas dan sistem-sistem norma itu sendiri. ${ }^{30}$ Dengan kata lain dapat dinyatakan bahwa hukum berdiri sendiri dan secara tegas terpisah dari moral (antara hukum yang berlaku dan hukum yang seharusnya, antara das sein dan das sollen). Pada konteks ini, tidak ada hukum lain selain perintah penguasa.

Dari beragam pemahaman di atas, maka dengan dasar positivisme hukum dapat dirumuskan ke dalam sejumlah premis dan postulat mengenai hukum, yakni: ${ }^{31}$

a. Tata hukum suatu negara berlaku bukan karena mempunyai dasar dalam kehidupan sosial, maupun dalam jiwa bangsa, dan juga bukan berdasarkan hukum alam, namun mendapat bentuk positifnya dari instansi yang berwenang;

b. Hukum harus dipandang semata-mata dari bentuk formalnya, dengan demikian harus dipisahkan dari bentuk materialnya;

\footnotetext{
${ }^{28}$ Theo Huijbers, Filsafat Hukum dalam Lintasan Sejarah, Pustaka Pelajar: Yogyakarta, 1993, hlm. 122

${ }^{29}$ Op. Cit., Erlyn Indarti, hlm. 21

${ }^{30}$ Hans Kelsen, "General Teori Of Law and State", diterjamahkan oleh Somardi, Teori Hukum Murni, Rimidi Press: Bandung, 1995, hlm. 115

31 Teguh Prasetyo dan Abdul Halim Barkatullah, Filsafat, teori, \& IImu Hukum Pemikiran: Menuju Masyarakat yang Berkeadilan dan BErmartabat, Rajawali Pers: Jakarta, 2014, hlm. 200-201
} 
c. Isi hukum atau materi hukum diakui ada, tetapi bukan menjadi bahan ilmu hukum, karena hal tersebut dapat merusak kebenaran ilmiah ilmu hukum.

\section{Keterkaitan antara Asas Kepastian Hukum dengan Penalaran Positivisme Hukum}

Dari keseluruhan pemahaman di atas maka dapat ditarik suatu pemahaman bahwa terdapat keterkaitan erat antara asas kepastian hukum dengan positivisme hukum. Benang merah yang menghubungkan asas kepastian hukum dengan positivisme ialah pada tujuan memberi suatu kejelasan terhadap hukum positif. Hukum dalam aliran yang positivistik mengharuskan adanya "keteraturan" (regularity) dan "kepastian" (certainty) guna menyokong bekerjanya sistem hukum dengan baik dan lancar. ${ }^{32}$ Sehingga tujuan kepastian hukum mutlak untuk dicapai agar dapat melindungi kepentingan umum (yang mencakup juga kepentingan pribadi) dengan fungsi sebagai motor utama penegak keadilan dalam masyarakat (order), menegakkan kepercayaan warga negara kepada penguasa (pemerintah), dan menegakkan wibawa penguasa dihadapan pandangan warga negara. ${ }^{33}$

Selain memberikan kejelasan, positivisme hukum bila diaplikasikan ke dalam pemikiran tentang hukum dalam ranah asasi, maka positivisme hukum ini menghendaki adanya pelepasan pemikiran meta yuridis mengenai hukum sebagaimana dianut oleh para pemikir hukum alam (naturalis). ${ }^{34}$ Oleh karena itu, setiap norma hukum harus eksis dalam alamnya yang objektif sebagai norma-norma positif, serta ditegaskan dalam wujud kesepakatan kontraktual yang konkret antara warga masyarakat dengan wakil-wakilnya. Disini hukum bukan lagi dikonsepsikan sebagai asas-asas moral meta yuridis yang abstrak tentang hakikat keadilan, melainkan ius yang telah mengalami positivisasi sebagai lex, guna menjamin kepastian mengenai apa yang terbilang sebagai hukum, dan apa pula yang sekalipun normatif harus dinyatakan sebagai hal-hal yang bukan terbilang hukum. ${ }^{35}$

Dari pernyataan tersebut di atas, maka dapat dipahami bahwa positivisme hukum menciptakan suatu hukum yang konkret dan terbebas dari konsepsi abstrak yang akan menciptakan ketidakpastian. Hal ini sejalan dengan maksud dan tujuan dari asas kepastian hukum yang mana menjamin agar para pencari keadilan dapat menggunakan suatu hukum yang pasti dan konkret serta objektif, tanpa adanya keterlibatan dari spekulasi-spekulasi ataupun pandangan yang subjektif.Seperti apa yang dikatakan oleh John Austin, bahwa kepastian hukum merupakan tujuan paling akhir dari positivisme hukum, dimana untuk

\footnotetext{
${ }^{32}$ Mirza Satria Buana, Op.Cit., hlm. 34

${ }^{33}$ A. Ridwan Halim, Evaluasi Kuliah Filsafat Hukum, Ghalia Indonesia: Jakarta, 1987, hlm. 166.

${ }^{34}$ Op.Cit., Teguh Prasetyo dan Abdul Halim Barkatullah, hlm. 196.

${ }^{35}$ Soetandyo Wignjosoebroto, Hukum, Paradigma, Metode dan Dinamika Masalahnya, Elsam \& Huma: Jakarta, 2002, hlm. 96
} 
mencapai kepastian hukum, maka diperlukan pemisahan antara hukum dari moral sehingga menghasilkan suatu sistem yang logis, tetap, dan bersifat tertutup (closed logical system). ${ }^{36}$

Dalam hemat penulis, asas kepastian hukum dapat dikatakan merupakan anak kandung dari penalaran positivisme terhadap hukum. Positvisme hukum seperti yang sebelumnya telah dijelaskan berusaha menciptakan suatu hukum yang objektif ataupun tertulis yang dibuat oleh negara untuk menciptakan keteraturan bagi masyarakatnya. Dengan hukum yang demikian maka akan menciptakan apa yang dikatakan sebagai asas kepastian hukum, dimana masyarakat tempat hukum berada terjamin secara pasti bahwa terdapat hukum yang mengaturnya tentang apa yang harus dilakukan dan tidak harus dilakukan. Oleh karena itu, dapat dikatakan bahwa positivisme hukum ini mensarikan nilainya untuk menciptakan suatu hukum yang jelas ke dalam asas kepastian hukum. Dengan demikian, hukum tidak berdasar pada spekulasi-spekulasi subjektif semata yang akan menjadikan hukum abu-abu dan tak Nampak kejelasan di dalamnya.

\section{Simpulan}

Dari berbagai penjelasan di atas maka diperoleh kesimpulan bahwa asas kepastian hukum dengan penalaran positivisme hukum memiliki benang merah yang menguntai keduanya. Gagasan utama dari positivisme hukum menjadi basic ratio logis dari munculnya asas kepastian hukum yang kemudian dikonkretisasi dalam hukum positif melalui peraturan perundang-undangan.

\section{DAFTAR PUSTAKA}

\section{Buku-Buku:}

Bruggink. Refleksi tentang IImu Hukum. Alih Bahasa: Arief Sidharta. Citra Adytya Bakti: Bandung. 1999.

Fung Yu-Lan. A Short History Of Chinese Philosophy. The Free Press: New York. 1966.

Halim, A. Ridwan. Evaluasi Kuliah Filsafat Hukum. Ghalia Indonesia: Jakarta. 1987.

Huijbers, Theo. Filsafat Hukum dalam Lintasan Sejarah. Pustaka Pelajar: Yogyakarta. 1993.

Mertokusumo, Sudikno. Bab-Bab Tentang Penemuan Hukum. Citra Aditya Bakti: Bandung. 1993.

Najwan, Johni. "Implikasi Aliran Positivisme Terhadap Pemikiran Hukum", Jurnal IImu Hukum Inovatif. Volume 2. Nomor 3. 2010.

Notohamidjojo, Soal-Soal Pokok Filsafat Hukum, BPK Gunung Mulia: Jakarta,1975.

\footnotetext{
${ }^{36}$ Op.Cit., Widodo Dwi Putro, hlm. 35
} 
Prasetyo, Teguh dan Barkatullah, Abdul Halim. Filsafat, teori, \& Ilmu Hukum Pemikiran: Menuju Masyarakat yang Berkeadilan dan Bermartabat. Rajawali Pers: Jakarta. 2014.

Putro, Widodo Dwi. Kritik Terhadap Paradigma Positivisme Hukum. Genta Publishing: Yogyakarta. 2011.

Rahardjo, Satjipto. IImu Hukum. Citra Aditya Bakti: Bandung. 2012.

Shidarta. Hukum Penalaran dan Penalaran Hukum.Genta Publishing: Yogyakarta. 2013. 2006.

Karakteristik Penalaran Hukum Dalam Konteks Keindonesiaan. Alumni: Bandung.

Soetiksno. Filsafat Hukum bagian 1.Pradnya Paramita: Jakarta, 2004.

Somardi. Teori Hukum Murni. Rimidi Press: Bandung. 1995.

Wignjosoebroto,Soetandyo Hukum. Paradigma, Metode dan Dinamika Masalahnya. Elsam \& Huma: Jakarta. 2002.

\section{Jurnal IImiah}

Atmaja, Dewa Gede. "Asas-Asas Hukum Dalam Sistem Hukum”. Jurnal Kertha Wicaksana. Volume 12. Nomor 2. 2018.

Prayogo, R. Tony. "Penerapan Asas Kepastian Hukum Dalam Peraturan Mahkamah Agung Nomor 1 Tahun 2011 Tentang Hak Uji Materiil Dan Dalam Peraturan Mahkamah Konstitusi Nomor 06/Pmk/2005 Tentang Pedoman Beracara Dalam Pengujian UndangUndang “. Jurnal Legislasi Indonesia. Volume 13. Nomor 2. 2016.

\section{Skripsi/Tesis/Disertasi/Pidato IImiah}

Buana,Mirza Satria. HubunganTarik-Menarik Antara Asas Kepastian Hukum (Legal Certainpi) Dengan Asas Keadilan (Substantial Justice) Dalam Putusan-Putusan Mahkamah Konstltusi. Yogyakarta: Tesis Magister Ilmu Hukum Universitas Islam Indonesia. 2010.

Indarti, Erlyn.Diskresi dan Paradigma Sebuah Telaah Filsafat Hukum. Disampaikan pada Upacara Penerimaan Jabatan Guru Besar dalam Filsafat Hukum pada Fakultas Hukum Universitas Diponegoro. Badan Penerbit Universitas Diponegoro: Semarang. 2010. 